\title{
SOME EFFECTS OF THE PHOTOPERIOD ON THE SHOOT GROWTH OF CHERRY SEEDLINGS \\ L. SMEETS
}




\title{
SOME EFFECTS OF THE PHOTOPERIOD ON THE SHOOT GROWTH OF CHERRY SEEDLINGS
}

\author{
L. SMEETS \\ Institute of Horticultural Plant Breeding, Wageningen, Netherlands \\ Received 6 Oct. 1956
}

\section{INTRODUCTION}

At our Institute a great many cherry seedlings are yearly grown from seed derived from crossings and open pollination in order to produce new varieties (3). For crossings in which early ripening varieties are used as seed parents, embryo cultures are vitally necessary for the production of seedlings. However, a number of plants thus grown show dwarfed growth. This is a phenomenon often described in the literature, but its exact cause is not known (1). A better knowledge of the influence of environmental factors on the growth and development of cherry seedlings might be of importance in solving this problem.

Moreover the fruit breeder is handicapped by the fact that his seedlings start fruiting only after a considerable length of time due to the existence of a juvenile phase i.e. the period between the germination of the seed and the moment at which flower initiation is possible. This phase might be shortened by using embryo-cultures (1), thus eliminating the period of stratification, or by enabling the seedlings to complete more than one growth cycle per year $(4,5)$ or both. Here, too, it may be of importance to know the influence of environmental conditions. From the literature it is known that the photoperiod is an important factor in the annual cycle of growth in woody plants, but little is known about fruit-trees (8). Therefore experiments on the influence of the photoperiod on the growth and development of cherry seedlings were started. In this paper some of the results so far obtained will be reported and discussed.

\section{MATERIAL AND METHODS}

First- and second-year cherry seedlings of Limburgse Boskriek ( $P$. avium L.) served as test plants. They were grown from seed supplied by the Netherlands General Inspection Service for Arboriculture (N.A.K.-B.).

The experiments were carried out in the phytotron of our Institute. For details of the equipment the reader is referred to a paper by BRAAK and SMEETS (2). In all experiments the plants received every day $8 \mathrm{hrs}$. basic illumination consisting of daylight given in a glasshouse from 8 a.m. till 4 p.m. Next the plants, which were placed on trolleys, were moved to air-conditioned rooms where they were either placed in darkness or received additional illumination consisting of 8 or $16 \mathrm{hrs}$. incandescent light. At 8 a.m. the following morning the plants were transferred again to the glasshouse, and so on. The radiant energy of the additional incandescent light between 4,000 and $7,200 \AA$ at the tip of the plants was about $1,200 \mathrm{~mW} / \mathrm{m}^{2}$. The plants were grown at a constant temperature of $20^{\circ} \mathrm{C}$ during day and night. In general the maximum deviation from the mean temperature was $1^{\circ} \mathrm{C}$ in the glasshouse, $\frac{1}{2} \mathrm{C}$ in the air-con- 
ditioned rooms. Only on exceptionally hot days did the temperature rise in the $20^{\circ} \mathrm{C}$ glasshouse to $25^{\circ} \mathrm{C}$ in the afternoon.

\section{EXPERIMENTAL RESULTS}

\section{Effect of the photoperiod on first-year seedlings}

In a preliminary experiment the influence of 8 and 16-hr. photoperiods on the cessation of the shoot growth of first-year seedlings was studied. The seed was stratified on September 3, 1952, sown on December 2, 1952, in seed-trays which were placed in a coldhouse. The young seedlings were pricked off in pots on March 12, 1953. The experiments were started on March 30, 1953.

It appeared that under an 8-hr. photoperiod shoot growth ceased in a number of plants at about the middle of June. At the end of June nearly all plants grown under an 8-hr. photoperiod had terminated growth. At about that time a number of plants grown under a 16-hr. photoperiod also ceased growth. However, some of these plants resumed growth after some time and terminated growth at the end of September, together with the plants that had been growing more or less continuously.

The experiment was repeated in 1954. The seed was stratified on September 30, 1953, and sown in seed-trays on December 29, 1953, which were placed in a coldhouse. The young seedlings were pricked off in pots on April 2, 1954. The experiment was started on May 19, 1954.

Table 1 shows that a large number of plants under both 8 and 16-hr. photoperiods ceased growth at the same time. However, some of the plants under an 8-hr. photoperiod ceased growth much sooner, while some of the plants under a 16-hr. photoperiod ceased growth considerably later. The latter consisted both of plants which grew more or less continuously and of plants which interrupted their growth for some time.

TABLE 1. EFFECT OF AN 8 AND 16-HR. PHOTOPERIOD ON THE CESSATION OF SHOOT GROWTH IN FIRST-YEAR SEEDLINGS OF LIMBURGSE BOSKRIEK ( $P$. avium L.)

\begin{tabular}{|c|c|c|c|c|}
\hline \multirow{2}{*}{ Dates } & \multicolumn{2}{|c|}{$\begin{array}{l}\text { 8-hr. photoperiod } \\
\text { (40 plants) }\end{array}$} & \multicolumn{2}{|c|}{$\begin{array}{c}\text { 16-hr. photoperiod } \\
\text { (37 plants) }\end{array}$} \\
\hline & Ceased & Not ceased & Ceased & Not ceased \\
\hline 9.6 .54 & 5 & 35 & - & - \\
\hline 24. 6.54 & 9 & 31 & - & - \\
\hline 2.7. 54 & 15 & 25 & 13 & 24 \\
\hline 8.7. 54 & 26 & 14 & 25 & 12 \\
\hline 14. 7.54 & 35 & 5 & 33 & 4 \\
\hline 22. 7.54 & 40 & - & 34 & 3 \\
\hline 11.8 .54 & 40 & - & 33 & 4 \\
\hline 20.8 .54 & 40 & - & 30 & 7 \\
\hline 14. 9.54 & 40 & - & 37 & - \\
\hline
\end{tabular}

The growth of the plants throughout the experiment is shown in Fig. 1, for both 8 and 16-hr. photoperiods. It appears that among the plants grown in an 8-hr. photoperiod those which terminated growth much earlier than the remainder only grow little. Hence their final length differs but little from the length these plants had at the moment at which the experiment was started. The other plants grown in short days also grew 


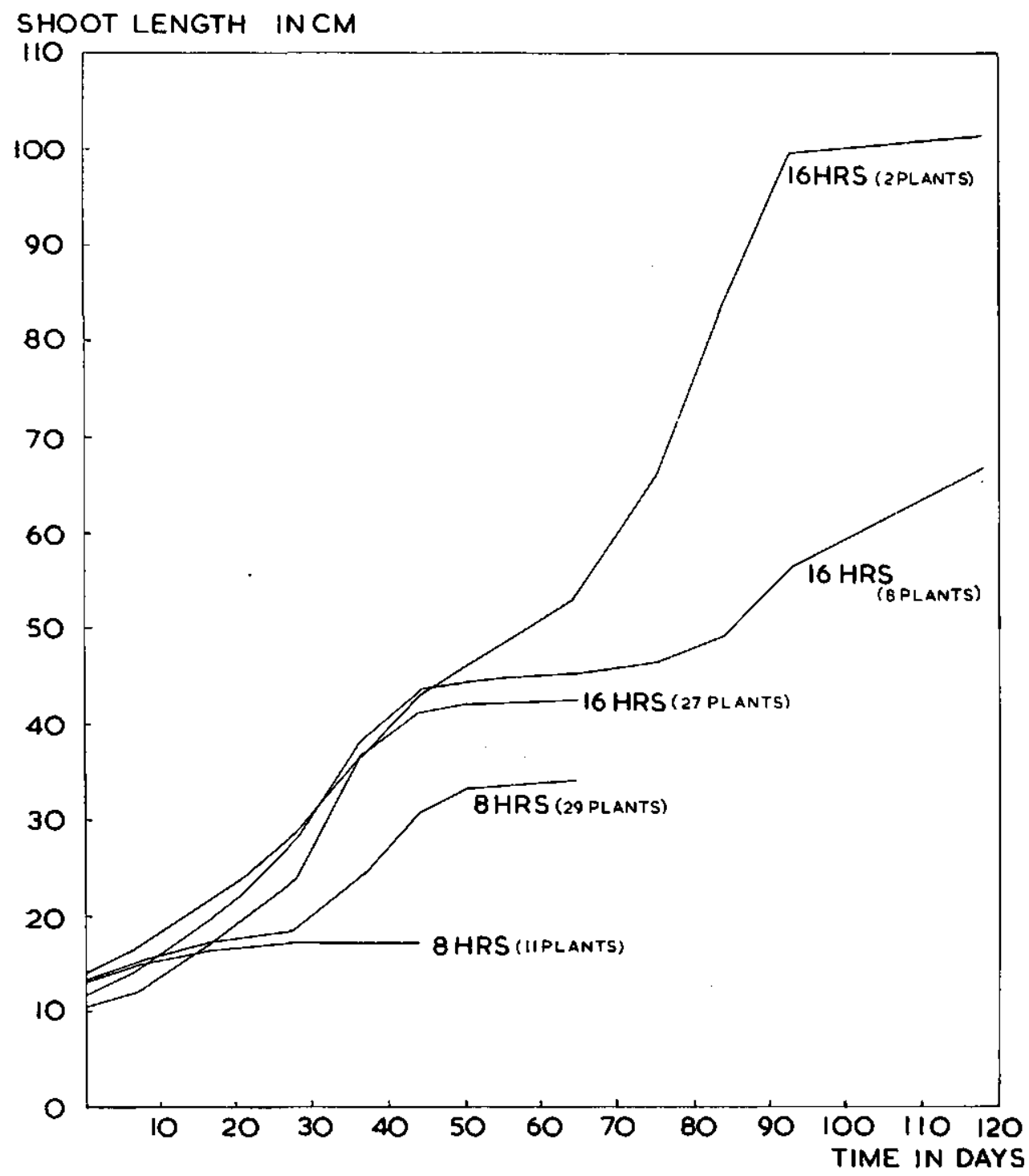

FIG. 1. THE COURSE OF GROWTH OF FIRST-YEAR SEEDLINGS OF LIMBURGSE BOSKRIEK ( $P$. avium L.) UNDER 8 AND 16-HR PHOTOPERIODS FROM THE BEGINNING OF THE EXPERIMENT UNTIL THE TERMINATION of shoot growth. Plant numbers are given between brackets

little at first, but before terminating their growth they showed a period of fairly rapid development. The behaviour of the majority of the plants grown in a 16-hr. photoperiod was very similar to that of most of the plants grown in an 8-hr. photoperiod except that the initial growth of the former was more rapid. Lastly there are the plants that in a 16hr. photoperiod terminate growth considerably later either by interrupting their growth for some time or by growing on more or less continuously. The course of growth of the 
former during their first growing period shows much similarity to that of the majority of the plants grown in a 16-hr. photoperiod, whereas the course of growth of the latter only does so to a smaller extent. It should be noted that the total number of plants that interrupt their growth and of those which grow on more or less continuously (Fig. 1) is larger than would appear from Table 1. This is due to the fact that the plants which interrupt their growth neither resume nor terminate growth at the same time.

\section{Effect of the photoperiod on second-year seedlings}

The first observations on the effect of 8 and 16-hr. photoperiods in second-year seedlings were made on plants already used in the preliminary experiment with firstyear seedlings. In order to cause the plants to shed their leaves and to break the dormancy of their buds it was found necessary to subject the plants first to a low temperature treatment ( 10 weeks at a constant temperature of 6 to $7^{\circ} \mathrm{C}$ proved to be sufficient). After a period of fairly low temperatures in a coldhouse the plants were placed again at a constant temperature of $20^{\circ} \mathrm{C}$ under an 8 and 16-hr. photoperiod. The plants grown under 8 and 16-hr. photoperiods in the first year were randomly distributed between the two groups in the second year. Both groups of seedlings apparently ceased shoot growth at the same time.

In another experiment started on May 22, 1954, the influence of 8 and 16-hr. photoperiods was studied on seedlings that had been grown out of doors in 1953, and which were lifted on May 7, 1954, and then placed in 20-cm pots. They were cut back to a height of about $10 \mathrm{~cm}$, while only one of the developing buds was retained on each plant. It appeared that shoot growth under 8 and 16-hr. photoperiods ceased at about the same time. The mean stem length, however, was greater under a 16-hr. than under an 8-hr. photoperiod, but the average number of leaves was only slightly higher under a 16-hr. photoperiod. A statistical analysis showed that this difference was not significant. Consequently the difference in shoot length is caused by the fact that under a 16-hr. photoperiod the internodes are longer.

Finally the influence of 8,16 and $24-\mathrm{hr}$. photoperiods on the cessation of shoot growth was studied. First-year seedlings grown in pots out-of-doors were placed in $18-\mathrm{cm}$ pots on October 6,1955 . In the first year of growth most of these plants interrupted their growth for a longer or shorter time, while some of the plants only grew

TABle 2. EfFect of 8, 16 AND 24-HR. PHOtoperiods ON THE CESSATION OF THE ShoOT GROWTH IN SECOND-YEAR SEEDLINGS OF LIMBURGSE BOSKRIEK $(P$. avium L.)

\begin{tabular}{|c|c|c|c|c|c|c|}
\hline \multirow{2}{*}{ Dates } & \multicolumn{2}{|c|}{$\begin{array}{l}\text { 8-hr. photoperiod } \\
\text { (42 plants) }\end{array}$} & \multicolumn{2}{|c|}{$\begin{array}{l}\text { 16-hr. photoperiod } \\
\text { (42 plants) }\end{array}$} & \multicolumn{2}{|c|}{$\begin{array}{c}\text { 24-hr. photoperiod } \\
\text { (42 plants) }\end{array}$} \\
\hline & Ceased & Not ceased & Ceased & Not ceased & Ceased & Not ceased \\
\hline 6. 3.56 & 9 & 33 & 7 & 35 & 5 & 37 \\
\hline 13. 3. 56 & 24 & 18 & 25 & 17 & 17 & 25 \\
\hline 20. 3. 56 & 39 & 3 & 38 & 4 & 33 & 9 \\
\hline 27. 3.56 & 40 & 2 & 40 & 2 & 37 & 5 \\
\hline 4. 4.56 & 40 & 2 & 41 & 1 & 40 & 2 \\
\hline 27. 4. 56 & 42 & - & 41 & 1 & 42 & - \\
\hline 17. 5.56 & 42 & - & 42 & - & 42 & - \\
\hline
\end{tabular}




\section{SMEETS}

during a relatively short period. They were brought indoors on January 11,1956 , and cut back to within a length of $10 \mathrm{~cm}$, while only one of the developing buds was retained. The experiment was started on February 2, 1956.

Table 2 shows that even in a 24-hr. photoperiod growth ceased at about the same time as under an 8 and 16-hr. photoperiod, despite differences in the growth habits of the plants in their first year of growth mentioned above.

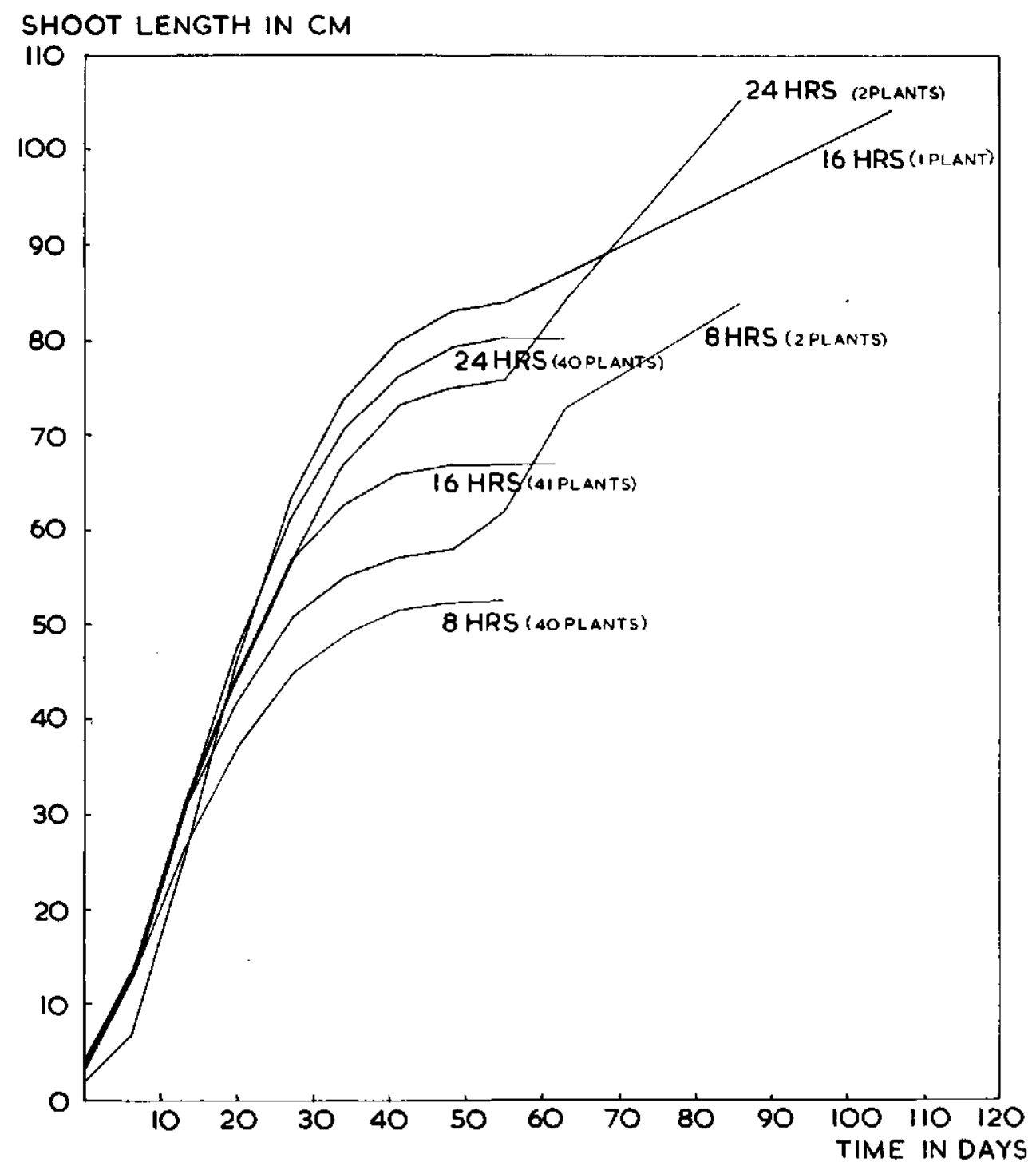

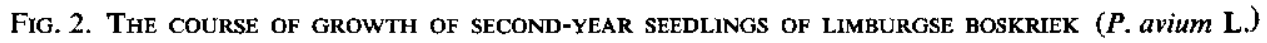
UNDER 8, 16 and 24-HR PHOTOPERIODS FROM THE BEGINNING OF THE EXPERIMENT UNTIL THE termination of SHOOT growth. Plant Numbers are given between brackets 
The average shoot length was greatest in a $24-\mathrm{hr}$. photoperiod while it was greater in a 16-hr. than in an 8-hr. photoperiod (Fig. 2). There was no difference in the average number of leaves under 8 and 16-hr. photoperiods (18.1 and 17.9 respectively), whereas slightly more leaves were produced under a 24-hr. photoperiod (20.0). A statistical analysis showed that this difference was significant. Consequently the difference in shoot length between the 3 treatments was mainly caused by differences in internodelength, which was longest under a $24-\mathrm{hr}$. photoperiod and longer under a 16-hr. than under an 8-hr. photoperiod.

\section{Discussion}

In the previous section it was shown that under the conditions of these experiments first- and second-year cherry seedlings respond differently to the photoperiod with respect to the termination of shoot growth.

In their first year of growth many of the plants under 8 and 16-hr. photoperiods terminated growth simultaneously. However, some of the plants under an 8-hr. day terminated growth much sooner, while a number of the plants grown under a 16-hr. day terminated their growth considerably later. In the second year of growth the plants under 8 and 16-hr. days terminated their growth at about the same time.

Similar results were obtained by WAREING $(6,7)$ who studied the influence of the photoperiod on the growth of Pinus silvestris. In the first year of growth the seedlings under short days terminated their growth about 4 weeks earlier than under long days. Differences in behaviour between the plants under short or long days are not mentioned. In the second and later years growth was terminated at the same time.

These differences are explained by WAREING (7) as being due to the fact that the duration of shoot growth of first-year seedlings is not predetermined by the number of initials already laid down in the resting bud, as in second-year and older seedlings. From the results of our experiments a satisfactory explanation of the differences in behaviour between first- and second-year cherry seedlings cannot yet be given. In a following paper on the influence of the temperature this problem will be discussed further.

\section{SUMMARY}

For cherry breeding it may be of importance to know the factors affecting the growth and development of cherry seedlings. Since it is known from the literature that the photoperiod is an important factor in the annual growth cycle in woody plants, experiments on the influence of the photoperiod were started in the phytotron of our Institute.

The effect of 8 and 16-hr. photoperiods on the shoot growth of first- and second-year seedlings of Limburgse boskriek ( $P$. avium L.) was studied at a constant temperature of $20^{\circ} \mathrm{C}$. In one experiment the influence of a $24-\mathrm{hr}$. photoperiod in second-year seedlings was also studied.

It was found that under the conditions of these experiments first- and second-year cherry seedlings respond differently to the photoperiod as regards termination of shoot growth. In first-year seedlings many of the plants under 8 and 16-hr. photoperiods terminated their growth at the same time. However, some of the plants under an 8-hr. 


\section{SMEETS}

photoperiod terminated growth much sooner, while a number of plants grown under a 16-hr. photoperiod terminated their growth considerably later. In second-year seedlings growth was terminated at about the same time under 8, 16 and 24-hr. photoperiods.

\section{SAMENVATTING}

\section{Enige effecten van de daglengte op de scheutgroei van kersezaailingen}

Voor het veredelingswerk bij de kers kan het van belang zijn de factoren die invloed uitoefenen op de groei en ontwikkeling van kersezaailingen nader te leren kennen. Aangezien uit de literatuur bekend is dat de daglengte een belangrijke factor is in de jaarlijkse groeicyclus van houtige planten, werd in het fytotron van ons Instituut een onderzoek begonnen over de invloed van de daglengte.

Onderzocht werd het effect van een korte en lange dag (8 en 16 uur) op de scheutgroei van zaailingen van Limburgse Boskriek ( $P$. avium L.) in hun 1e en 2e groeijaar bij een constante temperatuur van $20^{\circ} \mathrm{C}$. In één proef werd bovendien de invloed van continu licht in het $2 \mathrm{e}$ groeijaar bestudeerd.

Gebleken is dat onder de condities van deze proeven de zaailingen in hun 1e en $2 \mathrm{e}$ groeijaar verschillend reageren op de daglengte wat betreft het afsluiten van de scheutgroei. In het le groeijaar gaat een groot gedeelte van de planten onder korte en lange dag gelijktijdig in rust. Een deel van de planten onder korte dag gaat echter aanmerkelijk eerder in rust; een deel van de planten onder lange dag aanzienlijk later. In het 2e groeijaar gaan de planten onder korte en lange dagen en continu licht bijna alle gelijktijdig in rust.

\section{LITERATURE CITED}

1. BRAAK, J. P., Effects of some internal and external factors on the embryo and seedling development of the cherry. Report of the Fourteenth International Horticultural Congress 1955 (in the press).

2. BraAK, J. P. and SmeETs, L., The phytotron of the Institute of Horticultural Plant Breeding at Wageningen, Netherlands. Euphytica 5 (1956): 205-217.

3. GERRITSEN, C. J., Improvement of the cherty varieties used in the Netherlands. Euphytica 5 (1956): 101-116.

4. Potapenko, J., Acceleration of development and fruiting of fruit-tree seedlings. Comptes Rendus (Doklady) de l'Académie des Sciences de l'URSS 23 (1939): 839-842.

5. SMEETS, L., A note on the shortening of the juvenile phase in cherry seedlings. Euphytica 5 (1956): $117-118$.

6. WAREING, P. F., Growth studies in woody species I. Photoperiodism in first-year seedlings of Pinus silvestris. Physiol. Plant. 3 (1950): 258-276.

7. Wareing, P. F., Growth studies in woody species II. Effect of day-length on shoot-growth in Pinus silvestris after the first year. Physiol. Plant. 3 (1950): 300-314.

8. WAREING, P. F., Photoperiodism in woody plants. Ann. Rev. Plant Physiol. 7 (1956): 191-214, 


\section{VAN HET INSTITUUT VOOR DE VEREDELING VAN TUINBOUWGEWASSEN}

50. Algemene Veredelingsdagen 1952. Verslag van voordrachten en discussies. Juni 1953 ..... . f 1,50

51. Sneep, J. Practijkproeven met Spitskool 1949-1950 en 1950-1951. Juli $1953 \ldots . . . . . . .60,65$

52. Boom, B. K. International reglement voor de naamgeving van gekweekte planten . . . . f 0,75

3. Kronenberg, H. G, en F. Garretsen, Opbrengstproeven met aardbeiklonen. November 1953 ... . . f 0,35

54. Veredelingsdag Groentegewassen 1953. Verslag van voordrachten en discussies. December $1953 .{ }^{\circ}$. U Uitverkoche

56. Banga, O. Taproot-problems in the breeding of root vegetables ............. . . f 0,25

57. Jensma, J. R. en A. Kraai. Practijkproeven met Rode Kool 1950-1951. Juni 1954 . . . . . . . . f f 1,10

58. Jensma, J. R, en A. Kraai. Practijkproeven met Spruitkool 1950-1951. Juli 1954......... f 0,85

59. Veredelingsdag Fruitgewassen 1954. Verslag van voordrachten en discussies. Augustus 1954 ... . . . 0,95

60. Kraai, A. The use of Honey-bees and Bumble-bees in breeding work. September 1954 . . . . . f 0.45

61. Jensma, J. R. en A. Kraai. Practijkproeven met Witse Kool 1952-1953. Februari 1955 . . . . . . . f 1,35

62. Banga, O. en J. $W$. de Bruyn. Selection of Carrots for Carotene Content. Februari 1955 . . . . . . f 0,25

63. Kronenberg, H. G. en L. M. Wassenaar. Practijkproeven met aardbeirassen 1952-1954. April 1955 . f0,90

64. Keuls, M. and J. W. Sieben. Two statistical problems in plant selection. April 1955 . * - - . 0,35

65. Banga, $\mathbf{O}$. The Institute of Horticulcural Plant Breeding. April 1955 ..................

66. Banga, 0 . Uienveredeling met gebruikmaking van inteeit en herstel door heterosis. Juni 1955 ... . . . . f 0,30

67. Banga, O. Carrot yield analysis. September 1955 . f 0,30

68. Banga, O., J. W. de Bruyn and L. Smeets. Selection of carrots for carotene content. II Sub-normal content at low temperature. September 1955 . 0,25

69. Braak, J. P. Effect of temperature and light on June Yellows in strawberries. September $1955 \ldots . .\{0,25$

70. Banga, $\mathbf{O}$. De ontwikkeling van de rassensituatie bij groentegewassen. Oktober 1955

0,25

71. Bruyne, A.S. de. Tendenzen in de oncwikkeling van het Nederlandse fruitsortiment. Oktober 1955 . . . f 0,40

72. Banga, O. Praktijkproeven met Knolselderij 1953-1954. November 1955 ............ f 0,30

73. Floor, J., Proeven met stekken onder waterverneveling. April 1956 . . . . . . . . . . . .

74. Andeweg, J. M. en J. H. Ruyten. Praktijkproeven met Tomaten 1954-1955. April 1956. . . . . i f 0,40 ven met Stoksnijbonen 1953-1954. Mei 1956 . 0.35

76. Banga, $\mathbf{O}$. en J. L. van Bennekom. Praktijkproeven met Ronde Witpunt Radijs 1953-1954. Mei 1956 . . . f 0,55

77. Smeets, L. and Hester G. Kronenberg. Runner formation on strawberry plants in autumn and winter.
Smeets, L. Runner formation on strawberry plants in autumn and winter. II. Influence of the light intensity on the photoperiodical behaviour. Juni 1956 . . . f 0,30

78. Smeets, L. Influence of the temperature on runner production in five strawberry varieties. Juni 1956 . . f 0,25

79. Smeets, L, and L. M. Wassenaar. Problems of heat spot in Fragaria vesca $L$. when indexing strawberry selections for viruses. Juni 1956

30. Banga, $\boldsymbol{O}$. and J. W. de Bruyn. Selection of carrots for carotene content. Ill Planting distances and ripening equilibrium of the roots. Juni 1956 ....... . . o, 0,35

81. Banga, $O$. International conference on the improvement and on the standardization of vegetable varieties ac Wageningen. Netherlands, on August 26 and $27,1955$. August 1956 .............. . . 0,75

82. Floor, J. Proeven mec vermeerdering van houtige gewassen. September 1956 . . o,80

83. Gerritsen, C. J. Improvement of the cherry varieties used in the Netherlands. Oktober 1956 ... . . f 0.35

84. Gerritsen, C.J. Research offered new possibilities for nut growing in the Netherlands. Oktober 1956 . . f 0,25

85. Andewer, J.M. The breeding of scab-resistant frame cucumbers in the Nectherlands. Oktoker 1956 . . . f 0,30

66. Zeilinga, A. E. An improved acetic orcein squash method for serial cytological preparations. Oktober 1956 f 0,20

87. Braak, J.P. and L.Smeets, The Phytotron of the institute of Horticultural Plant Breeding at Wageninger, the Netherlands. Oktober 1956.......... f 0,30

88. Banga, $O$. and $L$. Smeets. Some effects of the photoperiod on growth and pithiness of radish. Oktober 1956. . . . . . f 0,30

89. Kho, Y, O. and J. P. Braak. Reduction in the yield and viability of carrot seed in relation to the occurence of the plant bug Lygus campestris L. Oktober 1956 . . f 0,35

0. Terpstra, $W$. Some factors influencing the abscission of debladed leaf petioles. Oktober 1956 . . . f 0,35

91. Keuls, M. en J. J. Post, Invloed van de temperatuur op de groei van asperges. Januari 1957 . . . f 0,70

92. Smeets, L. Some effects of the phatoperiod an the shoot groweh of cherry seedlings. Febr. 1957 . f 0,30

93. Elzenga, G. and J. W. de Bruyn. Interrelation of alkaloid content and stage of development of 1- and 2-year - old - Atropa belladonna L. Febr. 1957 . . . . . f 0,30

94. Elzenga, G., L. Smeets and J. W. de Bruyn. Influence of the temperature on growth and alkaloid content of first-year Atropa belladonna L. Februari 1957 f 0.25

95. Ferguson, J. H. A. Some applications of binomial probabifity paper in genetic analyses. Februari 1957 0,35

96. Jensma, J. R. Teelt en veredeling van bloemkool. Maart 1957$$
\text { f } 3,50
$$

97. Boom, B. K. Benaming, geschiedenis en kenmerken van een antal houtachtige planten. Nomenclature, history and characteristics of some woody plants. Maart 1957............. f 2,50

\section{PERSBERICHTEN UITSLAGEN PRACTIJKPROEVEN}

11- 3-'51, Uitslag Practijkproeven Westlandse Boerenkool 1949-1950.

3. 9.'51. Uitslag Practijkproeven Spitskool 1950-1951.

23- 1-'52. Uitslag Practijkproeven Vroege en Herfst Rodekool 1950-1951.

31- 3-'52. Uitslag Practijkproeven Spruitkool 1950-1951.

4-11-'52. Uitslag Practijkproeven Ronde Rode Radijs 1951-1952.

4-11-'52. Uitslag Practijkproeven Vroege Rijspeulen 1951-1952.

25-11'52. Uitslag Practijkproeven Lange Kroten 1951-1952.

23- 1-'53. Uitslag Practijkproeven Radijs Ront'a Scharlakenrode Extra Kortloof 1951-1952.

13- 5-'53. Uicslag Practijkproeven Bewaar Rode Kool 1951-1952.

10- 9-'53. Uitslag Practijkproeven Vroege Witte Kool 1952-1953.

18-12-'53. Uitslag Practijkproeven Herfst Witte Kool 1952-1953.

3- 6-'54. Uitslag Practijkproeven Bewaar Witte Kool 1952-1953.

17-11-'54. Uitslag Practijkproeven Stoksnijbonen 1953-1954

2-12-'54. Uitslag Practijkproeven Ronde Rode Witpunt Radijs 1953-1954.

12- 2-'55. Uitslag Practijkproeven Knolselderij 1953-1954.

1- 9.'55. Uitslag Practijkproeven Vroege Groene Savoye Kool 1954-1955.

14-11.'55. Uitslag Practijkproeven Tomaten 1954-1955.

27 12-'55. Uitslag Practijkproeven Witlof yroege trek 1954-1955.

2-3-'56. Uitslag Practijkproeven Witlof middelvroege trek 1954-1955

5-3-'56. Uitslag Practijkproeven Schorseneren 1954-1955.

28- 5-'56. Uitslag Practijkproeven Savoye Kool 1954-1955.

28- 5-'56. Uitslag Practijkproeven Witlof koude kuil en meilof 1954-1955.

30- 7-156. Uitsiag Practijkproeven Tuinbonen 1955-1956.

1- 9-'56. Uitslag Praktijkproeven Amsterdamse Bakwortel 1955-1956

1- 9-'56. Uitslag Praktijkproeven Vroege Rode Kool 1956

1- 9-'56. Uitslag Praktijkproeven Platronde Kroten 1955-1956

20- 9-'56. Uitslag Praktijkproeven Pronkbonen 1955-1956.

26-11-'56. Uitslag Praktijkproeven Herfstprei 1955-1956.

31- 1-'57. Uitslag Praktijkproeven Winterwortelen 1955-1956. 


\section{RASSENLIJSTEN ${ }^{1}$ ) \\ UITGEGEVEN DOOR HET INSTITUUT VOOR DE VEREDELING VAN TUINBOUWGEWASSEN}

Achtste Beschrijvende Rassenlijst voor Fruit. 1957. . f 1,75 Negende Beschrijvende Rassenlijst voor Groentegewassen. 1957. Redacteur Dr. O. Banga . . . . . f 1,75

\section{PUBLIKATIES VAN HET INSTITUUT VOOR DE VEREDELING VAN TUINBOUWGEWASSEN IN ANDERE ORGANEN OF IN BOEKVORM EVENTUEEL IN SAMENWERKING MET ANDERE INSTELLINGEN ?)}

De publikaties, waarvan prijs èn uitgever worden vermeld zijn verkrijgbaar in de boekhandel. Overigens wende men zich cot de opgegeven bronneri of tot de bibliotheek van hec I.V.T.

Boom, B. K. Cotoneaster wardii en verwante soorten. De Boomkwekerij t1, 1955: 3.

Gerritsen, C. J. Zit er wat in de teelt van hazelnoten? De Fruitteelt 45, 1955: 865

Kronenberg, H. G. Aardbeien. Wat moeten we toch planten? De Fruitceelt 45, 1955 : 866-867.

Gerritsen, C. J. Gaat U kersen planten? De Fruitteelt 45 1955: $909-910$

Burg, J. P. L. L. A. en G. Elzenga. Rapport over een studiereis aangaande de teeit en verwerking van geneeskrachtige en aromatische gewassen in Duitsland en Frankrijk $116 \mathrm{t} / \mathrm{m}$ 31 augustus 1955). V.N.K.-Nieuws, september 1955: 92-99.

Boom, B. K. Sorbus pratti en S. koeneana. De Boomkwekerij 11, $1955: 27$

Elzenga $G$. Het rooien van de wortels van Angelica en Valeriaan. V.N.K.-Nieuws, november 1955: 110-111

Elzenga, G. Pepermunt opnieuw inplanten. V.N.K.-Nieuws, november 1955: 112

Boom, B, K. Vraagstukken rondom het Cotoneaster-sortiment. De Boomkwekerij 11, 1955, 41-42.

Jensma, J. R. Rassenkeuze bij bloemkool. Groenten en Fruit 11, 1956: 721

Bruyne, A. S. de. Nieuwe appelrassen tot James Grieve. De Fruitwereld 1, 1956; no 4; 8-9.

Boom, B. K. Cercidiphyllum. De Boomkwekerij 11, 1955: 27

Broertjes, C. Reactie op vtaagstukken rondom het Cotoneastersortiment. De Boomkwekerij 11, 1956: 67-68

Broertjes, C. Veredeling op ziekteresistentie bij roten. De Boomkwekerij 11, 1956: 73.

Boorn, B, K. Acer platanoides, reitenbach' en ,rubrum De Boomkwekerij 11, 1956: 74.

Bruyn, J.W. de. De exportcontrole van kruiden in 1955. V.N.K.-Nieuws, januari 1956: 134-135.

Boom, B. K. Buxus, buksus of buks. De Boomkwekerij 11 1956: $80-81$.

Boom, B. K. Drie nieuwe witgen. De Boomkwekerij 11, 1956: 81-82.

Boom, B. K. Enkele bontbladige bomen. De Boomkwekerii I1, $1956: 88$.

Boom, B. K. Een nieuwe monographie over het geslacht Philadelphus. De Boomkwekerij 11, 1956: 96-97.

Gerritsen, C. J. Zal de noot een deugd worden? De Fruitwereld 1, 1956; no. 14: 5 .

Banga, $\mathbf{O}$. Enkele opmerkingen naar aanieiding van een internationale conferentie. Zaadbelangen 10, 1956: 101-102.

Kronenbers, H. G. Strawberry growing in the Netherlands. American Fruic Grower 76, 1956; no. 4: 77

Elzenga, G. Lobelia inflata. V.N.K.-Nieuws, maart 1956: 163166.

Boom, B. K. Variëteit en cultivar. De Boomkwekerij 11, 1956: $112-113$.

Andeweg, J. M. Vroegrijpende moneymaker's. Zaadbelangen $10,1956: 145$

Boom, B. K. Verwarring over de plancennamen. Vakblad voor de Bloemisterij 11, 1956: 130-131.

Gijsbers, J. W. Ruimcebesparing bij de opberging van dia's en negatieven. Meded. Dir. Tuinbouw 19, 1956:298-300

Boom, B. K. Over een verzameling prijscouranten. De Boomkwekeril 11, 1956: 128-129.

Boom, B. K. Een Amerikaan over Boskoop. De Boomkwekerif 11, 1956: 130.
Huyskes, I. A. Klauwenselectie bij asperges geeft goede resultaten. Boer en Tuinder (Land en Vee) 10, 1956; no. $482: 17$.

Koot, Y. v. en J. M. Andeweg. De groenteteelt in Amerjka. 's-Gravenhage, C.O.P. 1956. $149 \mathrm{blz}$, 7,00.

Banga, 0 . Kweker en overheid in de sector groentezaden. Zaadbelangen 10, 1956: 189-190.

Kho, $\mathbf{Y}$. O. Opbrengstvermindering en kiemkrachtyerlaging van wortelzaad als gevolg van aantasting door wancsen. Zaadbelangen 10, 1956: 193-194.

Elzenga, G. Digitalis lanata Ehr. V.N.K.-Nieuws 1956: 167-170, 193-199.

Andeweg, J. M. Rationalisatie en rassenkeure. Groenten en Fruit 12, 1956: 111

Kho, Y, O.en I. P. Braak. Opbrengstvermindering en kiemkrachtyerlaging van wortelzad als gevolg van aantasting door wantsen. Meded. Dir. Tuinb. 19, 1956: 440-445,

Kronenberg, H. G. Praktijkproeven met aardbeien in 1956 De Tuinderij 36, 1956, no 33: 1-3. Groenten en Fruit 12, 1956: 177 .

Floor, J. en P. A. Wezelenburg. Stekken onder plastic. De Boomkwekerij, 11, 1956: 174-175.

Terpstra, $\mathbf{W}$. Some factors influencing the abscission of debladed leaf petioles. Acca Botanica Neerlandica 5, 1956: $157-170$

Bruyne, A. S. de, Trends and developments in Dutch varieties. The Commercial Grower 1956, no 3165 : $419-422$.

Smeets, L. A note on the shortening of the juvenile phase in cherry seedlings. Euphytica 5, 1956: 117-118.

Boertjes, C. Vorstschade aan Rhododendronvariëteicen in in 1956. De Boomkwekerij 11, 1956: 187-189.

Rodenburg, C. M. Het kweken van wolfresistente spinazierassen. Zaadbelangen 10, 1956: 325-326.

Andeweg, J. $M$. Een waardevolie rroege kruisingsouder. Zaadbelangen 10, 1956: 344.

Huyskes, J. A. en C. M. Rodenburg. Internationale samenwerking bij het onderzoek van slarassen. Meded. Dir. Tuinb. 19, 1956: 823:826.

Gerritsen, C. I. De teelt van buitenperziken I. II. HIt IV Groencen en Fruit 12, 1956: 537-538; 569-570; 603 628-629.

Gerritsen, C. J. De Feyoa, aan nieuw cultuurgewas? Meded. Dir. Tuinb. 19, 1956: 889-894.

lensma, J. R. Sluitkoolrassen. Wageningen, I.V.T. 1956 150 blz. f13.50.

Floor, J. Planten in plastic. Wageningen, 1.V.T., 1956. f 0.35

Elzenga, G. De teelt van Valeriaan. V.N.K.-Nieuws 4 , 1956: 234-236.

Elzenga, G. Het mechanisch rooien yan Valeriaan. V.N.K. Nieuws 4, 1956: 246.

Eizenga, G. Het opkweken van plantmateriaal van Levisticum en Rheum. V.N.K.-Nieuws 4, 1956: 246-247

Elzenga, G. Roest in munt. Zou gier helpen? V.N.K.Nieuws 4, 1956: 247.

Elzenga, G. Mechanisch planten van Valeriaan blijkt zeer goed mogelijk. V.N.K.-Nieuws 4, 1956: 248-249.

Jzenga, $G$. De oogstdatum van Digitalis lanata. V.N.K. Nieuws 4, 1956: 249-250.

Giessen, A. C. $\mathbf{d}$ d. en A. v. Steenbergen. Een nieuwe methode voor de toetsing van bonen op resistentie tegen vlekziekte. Zaadbelangen 11, 1957: 26-27.

l) Zolang de voorraad strekt kunnen deze publikaties franco worden toegezonden, na ontvangst van het vermelde bedrag op giro no. 425340 van het Insticuut voor de Veredeling van Tuinbouwgewassen, S. L. Mansholtlaan 15 te Wageningen onder vermelding van wat verlangd wordt; ook bestaat de mogelijkheid deze publikaties uit de bibliotheek van het I. $V$.T. te lenen.

2) Eerder verschenen publikaties zijn vermeld achterin in de Mededelingen nos $1 \mathrm{t} / \mathrm{m} 89$. 